Tropical Journal of Pharmaceutical Research September 2017; 16 (9): 2169-2178

ISSN: 1596-5996 (print); 1596-9827 (electronic)

(C) Pharmacotherapy Group, Faculty of Pharmacy, University of Benin, Benin City, 300001 Nigeria.

All rights reserved.

Available online at http://www.tjpr.org

Original Research Article

http://dx.doi.org/10.4314/tjpr.v16i9.18

\title{
Evaluation of anti-leishmanial and antibacterial activity of Waldheimia tomentosa (Asteraceae), and chemical profiling of the most bioactive fraction
}

\author{
Manisha Bhatnagar ${ }^{1}$, Anupama Sharma Avasthi ${ }^{1}$, Sarman Singh ${ }^{2}$ and Sabari \\ Ghosal $^{1 *}$ \\ ${ }^{1}$ Centre for Plant and Environmental Biotechnology, Amity Institute of Biotechnology, Amity University, Noida 201303, \\ ${ }^{2}$ Department of Clinical Microbiology \& Laboratory Medicine, AlIMS, Ansari Nagar, New Delhi 110029, India \\ ${ }^{*}$ For correspondence: Email: sabarighosal@gmail.com; Tel: +91-120-4735614
}

Sent for review: 19 April 2017

Revised accepted: 20 August 2017

\begin{abstract}
Purpose: To evaluate the anti-leishmanial and antibacterial activities of a relatively unexplored whole plant of Waldheimia tomentosa (Asteraceae) and the chemical profiling of its most bioactive fraction. Methods: The whole plant material was extracted with methanol - water $(9: 1)$ and fractionated into $n$ hexane $\left(\mathrm{C}_{6} \mathrm{H}_{14}\right.$ or $n$-Hex), dichloromethane $\left(\mathrm{CH}_{2} \mathrm{Cl}_{2}\right.$ or $\left.D C M\right)$, ethyl acetate $\left(\mathrm{C}_{4} \mathrm{H}_{8} \mathrm{O}_{2}\right.$ or EtOAc) fractions and aqueous residue. The fractions were screened for leishmanicidal activity against promastigotes and intracellular amastigotes of $L$. donovani, while antibacterial activity was evaluated against four multidrug resistant (MDR) clinical isolates by bioassay guided fractionation. Scanning Electron Microscopy (SEM) performed on S. aureus at the minimum inhibitory concentration (MIC). Chemical profiling of the most bioactive fraction was performed using gas chromatography-mass spectrometry (GC-MS).

Results: The most significant leishmanicidal activity was exhibited by $n$-Hex fraction against promastigotes (DD8 strain) with half maximal inhibitory concentration (IC $C_{50}$ of $89.85 \pm 0.84 \mu \mathrm{g} / \mathrm{mL}$ ) and intracellular amastigotes ( $I C_{50}$ of $48.3 \pm 0.40 \mu \mathrm{g} / \mathrm{mL}$ ). The same fraction also exhibited maximum potency against S. aureus and E.coli at MIC of between 62.5 and $125 \mu \mathrm{g} / \mathrm{mL}$. The fraction comprised mainly fatty acids and alkyl ketones. SEM examination performed on S. aureus at MIC revealed swelling and multiple blisters on cell surface compared to untreated control.

Conclusion: The profound antibacterial activity of Waldheimia tomentosa justifies the use of the plant in traditional medicine for stomach ache and food preservation.
\end{abstract}

Keywords: Waldheimia tomentosa, Antibacterial activity, Leishmanicidal activity, Stomach ache, Food preservation

\footnotetext{
Tropical Journal of Pharmaceutical Research is indexed by Science Citation Index (SciSearch), Scopus, International Pharmaceutical Abstract, Chemical Abstracts, Embase, Index Copernicus, EBSCO, African Index Medicus, JournalSeek, Journal Citation Reports/Science Edition, Directory of Open Access Journals (DOAJ), African Journal Online, Bioline International, Open-J-Gate and Pharmacy Abstracts
}

\section{INTRODUCTION}

The trans-Himalayan belt of Ladakh and Kashmir valley are rich in ethnobotanical wealth. The traditional medicine of this region uses a number of plant extracts or concoctions in combination with salts or minerals for numerous ailments like common infections, memory loss, osteoporosis, age related disorders, AIDS and cancer [1]. Due to extreme climatic condition, the plants produce a number of unique metabolites which help in their sustenance and various other ailments. Barring few scattered examples, the claim of local medical practitioner has been validated by modern scientific parameters. Isolated living environment and poor access to healthcare is a threat for the management of highly prevalent communicable diseases for e.g., tuberculosis 
(TB), visceral leishmaniasis (VL) and malaria in this region. Considering the importance, a relatively unexploredplant, Waldheimia tomentosa, commonly used in traditional medicine was selected for the present investigation.

Waldheimia tomentosa, known as white leaf ground daisy belonging to the family Asteraceae is a perennial herb growing on the stony slopes of the Himalayas, at altitudes of $3600-5000 \mathrm{~m}$. The plant is used for common infections, acidity, arthritis and rheumatism [2] in traditional medicine. Report of any pharmacological study was not available on $W$. tomentosa. Few secondary metabolites possessing antioxidant activity were reported from another species of Asteraceae family, Waldheimia glabra (Decne.) Regel [3]. A number of plants have been reported to have leishmanicidal activity against various forms of leishmanial parasites [4]. Visceral leishmaniasis; a vector-borne disease caused by $L$. donovani, is the second most dreaded parasitic disease after malaria, causing considerable morbidity and mortality [5]. The life cycle of Leishmania involves two forms, promastigote and amastigote; one which evolves and thrives extracellularly in flagellar form in the gut of sandfly vector and another which develops intracellularly in the mammalian host respectively [6]. Most of the existing drugs for the treatment of kala-azar provoke a number of side effects and require long-term treatment [7]. Hence, there is an urgent need to explore new drug candidates. It is established fact as scientific evidences also suggests that several plants are rich in bioactive chemical components and several drugs that are analogues of plant origin substances are available and being used in modern day medicine [8]. Therefore, for the development of alternative drug line to treat leishmaniasis and bacterial infections, $W$. tomentosa was considered for further investigation. This is the first report of investigation of the plant for antibacterial and antileishmanial activity along with chemical profiling of the most active fraction.

\section{EXPERIMENTAL}

\section{Chemicals and reagents}

Solvents used for extraction and fractionation were of analytical grade from Merck, India. All media was procured from HiMedia chemicals, India. Gas Chromatography and Mass Spectrometry analysis was performed on GCMSQ2010 Ultra, Shimadzu gas chromatograph coupled with a mass selective detector. The separation was achieved using SPB-5 fusedsilica capillary column $(30 \mathrm{~m} \times 0.25 \mathrm{~mm} \times 0.25$ $\mu \mathrm{m})$, Supelco, Sigma-Aldrich. SEM was performed on Zeiss Evo 40 electron microscope with magnifications ranging from $10 \mathrm{~K}$ to $25 \mathrm{~K}$

\section{Plant Material and bacterial strains}

W. tomentosa was procured from the natural habitat of Khardung La region of Ladakh (45005300 meters), in the flowering stage and was authenticated by Dr. S. Kitchlu, from Indian Institute of Integrative medicine, Jammu (India). A voucher specimen, bearing vocher number AUUP/AIB/2013/01 is kept at the herbarium of Amity Institute of Biotechnology, Amity University, Uttar Pradesh. MDR bacterial isolates, viz, S. aureus (2413), E. coli (2461), Acinetobacter sp (2457) and Serratia sp (2442), were obtained from $\mathrm{Dr}$ Kumardeep Dutta Choudhary, Department of Medical Oncology, Rajiv Gandhi Cancer Research Institute, Delhi, India with their respective antibiotic resistance profiles (Table 1).

\section{Preparation of plant extract}

Air dried whole plant material of $W$. tomentosa $(0.92 \mathrm{~kg})$ was crushed and extracted with organic solvents overnight. Next day, the mixture was sonicated twice in an ultrasonic bath at $35{ }^{\circ} \mathrm{C}$ for $30 \mathrm{~min}$, twice and filtered. The filtrate was collected and the residue was extracted with minimum volume of water. The combined organic extracts were concentrated under reduced pressure, below $50{ }^{\circ} \mathrm{C}$ while, the aqueous extract was concentrated in a lyophilizer. The concentrated organic fraction was resuspended in $75 \mathrm{~mL}$ of water, and was fractionated with the solvents in increasing order of polarity viz, $n$-Hex, DCM and EtOAc successively as described previously by Mishra et al [9]. The organic and aqueous (Aq) fractions were concentrated appropriately and dry weight of each fraction was recorded. Thereafter, the fractions along with aqueous extract were screened for antileishmanial and antibacterial activity.

\section{Phytochemical tests}

The presence of alkaloids, flavonoids, steroids, tannins, reducing sugar, cardiac glycosides, terpenoids, anthraquinones and phlobatanins were examined by the methods described by Rajesh et al and Sawant et al [10,11].

\section{Alkaloids}

Methanolic extract with $1 \mathrm{mg} / \mathrm{mL}$ concentration was taken in the test tube and $1 \mathrm{~mL} \mathrm{HCL}$ was added to the extract, thereafter is was gently heated and cooled for 10 mins and filtered. 
Table 1: Antibiotic resistance profiles of MDR clinical isolates

\begin{tabular}{lcccc}
\hline Antibiotic & $\begin{array}{c}\text { S. aureus } \\
(\mathbf{2 4 1 3 )}\end{array}$ & $\begin{array}{c}\text { Serratia sp. } \\
\mathbf{( 2 4 4 2 )}\end{array}$ & $\begin{array}{c}\text { Acinetobacter sp. } \\
\mathbf{( 2 4 5 7 )}\end{array}$ & $\begin{array}{c}\text { E. coli } \\
\mathbf{( 2 4 6 1 )}\end{array}$ \\
\hline Amikacin & $\mathrm{S}$ & $\mathrm{S}$ & $\mathrm{R}$ & $\mathrm{S}$ \\
Ampicillin & - & $\mathrm{R}$ & - & $\mathrm{R}$ \\
Ciprofloxacin & $\mathrm{S}$ & $\mathrm{R}$ & $\mathrm{R}$ & $\mathrm{R}$ \\
Ceftriaxone & $\mathrm{S}$ & $\mathrm{R}$ & - & $\mathrm{R}$ \\
Chloramphenicol & - & $\mathrm{R}$ & - & $\mathrm{R}$ \\
Gentamicin & $\mathrm{S}$ & $\mathrm{R}$ & $\mathrm{R}$ & $\mathrm{S}$ \\
Imepenem & $\mathrm{S}$ & $\mathrm{S}$ & $\mathrm{R}$ & $\mathrm{R}$ \\
Levofloxacin & $\mathrm{S}$ & $\mathrm{R}$ & - & $\mathrm{S}$ \\
Meropenem & $\mathrm{S}$ & $\mathrm{S}$ & $\mathrm{R}$ & $\mathrm{R}$ \\
Nalidixic acid & - & - & - & $\mathrm{S}$ \\
Nitrofurantoin & - & - & - & $\mathrm{R}$ \\
Norfloxacin & - & - & - & $\mathrm{R}$ \\
Ofloxacin & $\mathrm{S}$ & $\mathrm{R}$ & - & - \\
Piperacillin & $\mathrm{S}$ & $\mathrm{S}$ & $\mathrm{R}$ & $\mathrm{R}$ \\
Vancomycin & $\mathrm{S}$ & - & - & \\
Tobramycin & - & $\mathrm{R}$ & & \\
\hline R: Resistant; S: Sensitive & & & & \\
\end{tabular}

To the filtrate 2 - 3 drops of Dragendorff's reagent was added. The development of a creamy precipitate was indicative of the presence of alkaloids.

\section{Flavonoids}

Alkaline reagent test- methanolic extract was treated with $10 \% \mathrm{NaOH}$ solution, the change in the color to intense yellow indicates presence of flavonoid.

\section{Steroids}

The methanol extract $(1 \mathrm{mg} / \mathrm{mL})$ was dissolved in $10 \mathrm{~mL}$ of $\mathrm{CHCl}_{3}$ and conc. $\mathrm{H}_{2} \mathrm{SO}_{4}(5 \mathrm{~mL})$ was added from the sides of test tube. As the upper layer turns to brownish red color and $\mathrm{H}_{2} \mathrm{SO}_{4}$ layer showed greenish yellow fluorescence, indicates the presence of steroids.

\section{Tannin}

The methanol extract $(1 \mathrm{mg} / \mathrm{mL})$ was treated with $1 \mathrm{~mL} \mathrm{FeCl} 3$ and formation of green color indicated the presence of condensed tannins.

\section{Reducing sugars}

To the methanolic extract $(1 \mathrm{mg} / \mathrm{mL}), 4 \mathrm{~mL}$ of Fehling's solution A and B mixture (1:1) was added and was boiled in water bath for five minutes. Presence of free reducing sugars was indicated by brick-red precipitate.

\section{Cardiac glycosides (Keller-Killani's test)}

To the methanol extract, $2 \mathrm{~mL}$ glacial acetic acid containing one or two drops of $\mathrm{FeCl}_{3}$ was added.
A brown colored ring confirms the presence of cardiac glycosides.

\section{Triterpenoids}

Acetic anhydride $(2 \mathrm{~mL})$ was added to the methanolic extracts $(1 \mathrm{mg} / \mathrm{mL})$ and cooled well in ice. $\mathrm{H}_{2} \mathrm{SO}_{4}$ was added from the sides of test tubes. If color changes from violet to blue or green, presence of terpenes is indicated.

\section{Anthraquinones}

The methanolic extract was hydrolyzed with dilute $\mathrm{H}_{2} \mathrm{SO}_{4}, 2 \mathrm{~mL}$ of benzene and $\mathrm{NH}_{3}(1: 1)$ was added, formation of rose pink color suggests the presence of Anthraquinone.

\section{Phlobatannins}

When the methanol extract was boiled with $1 \%$ aqueous $\mathrm{HCl}$, deposition of a red precipitate confirms the presence of phlobatannins.

\section{Bacteria and culture media}

Four clinical isolates including Staphylococcus aureus (2413), Escherichia coli (2461), Acinetobacter sp. (2457) and Serratia sp. (2442) were grown on $5 \%$ Muller Hilton broth (MHB). Following initial incubation $\left(37^{\circ} \mathrm{C}\right.$, overnight in shaker incubator), secondary bacterial cultures were suspended in $15 \mathrm{~mL}$ of MHB and optical density readings were adjusted and compared to a 0.5 McFarland standard. For the MIC determination bacterial suspension of $5 \times$ $10^{6}$ colony-forming units (CFU) $\mathrm{mL}^{-1}$ was employed [12]. 


\section{Agar well diffusion assay}

Antibacterial activity of plant fractions was determined by agar well diffusion method as described by Rojas et al [13]. To the solidified Muller Hilton agar plates, $0.1 \mathrm{~mL}$ each of bacterial suspensions $\left(1 \times 10^{6} \mathrm{CFU} / \mathrm{mL}\right)$ were added and spread well with sterile glass spreader. Subsequently, wells of $6 \mathrm{~mm}$ size were punched aseptically with cork borer into the agar set plates and filled with $30 \mu \mathrm{L}$ of the plant extracts (the concentration of the extract employed was $30 \mu \mathrm{g} / \mathrm{mL}$ ). The extracts were prepared in $2 \%$ DMSO and water expect for the aqueous fraction which was dissolved in autoclaved distilled water. Standard antibiotic disc of tetracycline $(30 \mu \mathrm{g})$ was used as positive control and autoclaved distilled water was used as negative control. The plates were incubated at $37 \pm 2{ }^{\circ} \mathrm{C}$ for $24 \mathrm{~h}$ or overnight. The assay was performed in triplicate and the antibacterial activity was expressed as mean diameter of inhibition zones $(\mathrm{mm})$ with standard deviation produced by the tested fractions.

\section{Determination of minimum inhibitory concen- tration (MIC) and minimum bactericidal concentration (MBC)}

MIC was determined by broth dilution method described by Weigand et al [14]. The bacterial cultures were diluted in Mueller-Hilton broth and density adjusted to 0.5 McFarland turbidity. bacterial suspension $(0.5 \mathrm{~mL})$ containing $5 \times 10^{6}$ $\mathrm{CFU} / \mathrm{mL}$ was added to $4.5 \mathrm{~mL}$ of susceptibility test broth containing diluted extracts solution which was already prepared by two-fold serial dilution from the stock solution of extract starting from 1024 to $15.62 \mu \mathrm{g} / \mathrm{mL}$, in autoclaved tubes. Wells were reserved in each plate as control of sterility (where no inoculum was added), inoculum viability (where no sample solution was added) and DMSO inhibitory effect control. The plates were then incubated for $24 \mathrm{~h}$ at $37^{\circ} \mathrm{C}$. After $24 \mathrm{~h}$ of incubation, the absorbance was read at $570 \mathrm{~nm}$ in ELISA reader. MIC of antibiotic tetracycline was used as standard reference drug, determined in parallel experiment for comparison. The lowest concentration of the sample that prevented visible growth was considered as MIC of the extracts.

MBC assay was performed as described by Celiktas et al [15], with slight modifications. The wells in which no growth or complete absence of bacterial growth were identified, aliquots $(10 \mu \mathrm{L})$ of each well were transferred to Muller Hilton agar plates and incubated at $37^{\circ} \mathrm{C}$ for $24 \mathrm{~h}$. MHA plates with complete absence of growth of bacteria was examined as the minimum bactericidal concentration.

\section{Leishmanicidal assay}

Pan sensitive strain of $L$. donovani (DD8) was obtained from Department of Laboratory Medicine (AlIMS), New Delhi, India. The culture was routinely maintained at $24{ }^{\circ} \mathrm{C}$ in $\mathrm{M}-199{ }^{\circledR}$ (Gibco, USA) medium supplemented with penicillin $(100 \mathrm{U} / \mathrm{mL})$, streptomycin $(100 \mu \mathrm{g} / \mathrm{mL})$ (Invitrogen, USA) and $10 \%$ heat inactivated fetal calf serum (FCS; GIBCO $\AA$, USA).

Log phase promastigotes were added in 96-well microtiter plate with different concentrations of extracts $(250-15.6 \mu \mathrm{g} / \mathrm{mL})$ and incubated at 24 ${ }^{\circ} \mathrm{C}$ for $48 \mathrm{~h}$. Thereafter, $100 \mu \mathrm{L}$ of MTT $(5 \mathrm{mg} /$ $\mathrm{mL}$ ) solution was added to each plate and incubated for $4 \mathrm{~h}$ at $24^{\circ} \mathrm{C}$. Finally, $100 \mu \mathrm{L}$ of DMSO was added in each well to dissolve the formazan crystal produced, followed by $18 \mathrm{~h}$ of incubation. The absorbance was measured at $570 \mathrm{~nm}$ and DMSO (0.5\%) was considered as untreated control while, amphotericin $B$ and miltefosine $(1 \mu \mathrm{g} / \mathrm{mL})$ were used as reference standard drugs. Each experiment was performed in triplicates [16].

To produce intracellular amastigotes, J774G8 (5 $\times 10^{5}$ cells $\mathrm{mL}^{-1}$ ) macrophage cells were plated onto $13 \mathrm{~mm}$ coverslips in 24-well plates for $1 \mathrm{~h}$ at $37{ }^{\circ} \mathrm{C}$ in a $\mathrm{CO}_{2}$ incubator. Non adherent cells were removed and the cells were further incubated overnight. The cells which remained adhered to the plate were infected with $L$. donovani promastigotes at a parasite: macrophage ratio of 10: 1 and further incubated for $1 \mathrm{~h}$. Unbound promastigotes were removed by extensive washing with PBS (pH 7.2). The infected macrophages (intracellular amastigote form) were incubated with different concentrations of samples (as for promastigotes) and the mean percentage of viable amastigotes was calculated in comparison to control and the results were expressed as concentration inhibiting the parasitic growth. The leishmanicidal effect of each sample was expressed as half maximal inhibitory concentration $I_{50}$ values.

\section{Cell cytotoxicity assay}

Cell cytotoxicity assay was performed by MTT method as described by Kakad and Dhembare [17]. In brief, from chick embryo, fibroblast cells were obtained and cultured in DMEM medium supplemented with Fetal Bovine Serum (FBS) and tetracycline. The cells suspension $(2 \mathrm{~mL})$ was treated with sample solution at MIC and twice of MIC concentration. The 96-well plate 
was incubated aseptically in $\mathrm{CO}_{2}$ incubator for 24 $\mathrm{h}$ at $37{ }^{\circ} \mathrm{C}$. After incubation, cells were disaggregated using trypsin $(0.25 \%)$ and cell viability (\%) was calculated.

\section{GC-MS analysis}

The most potential bioactive, non-polar $n$-Hex fraction of $W$. tomentosa, was accurately weighed to $5 \mathrm{mg}$ and was dissolved in acetonitrile. The sample was centrifuged at 3000 rpm for $15 \mathrm{~min}$. The supernatant was concentrated to dryness and the residue was reconstituted with methanol as required. An aliquot of $1.0 \mu \mathrm{L}$ was injected for the GC-MS experiment. The GC-MS analysis was repeated three times on GCMS-Q2010 Ultra, Shimadzu gas chromatograph coupled with a mass selective detector. The injector and interface were operated at 260 and $270{ }^{\circ} \mathrm{C}$, respectively. The oven temperature was raised from 80 to 280 ${ }^{\circ} \mathrm{C}$ at a heating rate of $5{ }^{\circ} \mathrm{C}$ for $3 \mathrm{~min}$ and then isothermally held for $17 \mathrm{~min}$. Helium, at a flow rate of $1.0 \mathrm{~mL} / \mathrm{min}$, was used as a carrier gas. Sample solution $(1 \mu \mathrm{L})$ in methanol $(1: 100)$ was injected in pulsed split mode (first $3 \mathrm{~min}$ at 1.5 $\mathrm{mL} / \mathrm{min}$ and the rest time period at $1.0 \mathrm{~mL} / \mathrm{min}$; split ratio1:10). Mass selective detector operated at the ionization energy of $70 \mathrm{eV}$, in 40 - $650 \mathrm{amu}$ range with a scanning speed of $0.33 \mathrm{~s}$. Retention Indices $(\mathrm{RI})$ were determined in relation to a homologous series of $n$-alkanes $\left(C_{7}-C_{33}\right)$ under the same conditions. GC (FID) analysis was carried out under the same experimental conditions using the same column as described for GC-MS the percentage composition was computed from the GC peak areas without the use of correction factors. Peak identification was accomplished by comparison of their mass spectra with those stored on GC - MS databases (NIST 11 and Wiley 8).

\section{Preparation of cells for SEM}

Scanning Electron Microscopy (SEM) analysis was performed on $S$. aureus treated with MIC of
W. tomentosa $n$-Hex fraction. Bacterial cells were cultured to reach mid exponential growth phase in nutrient broth as described by Tang et al [18]. The cells were collected by centrifugation and washed thrice with sodium phosphate buffer. The samples were then fixed in $2.5 \%$ glutaraldehyde in $0.1 \mathrm{M}$ phosphate buffer, $\mathrm{pH} 7.3$, at $4{ }^{\circ} \mathrm{C}$ overnight, and post fixed in $1 \%$ osmium tetroxide in the phosphate buffer for $1 \mathrm{~h}$ at room temperature. This was followed by three washings in phosphate buffer for $10 \mathrm{~min}$ and subsequently dehydration by a series of ethanol concentrations (20,50,70, 90 and $95 \%)$, for 15 min each. The samples were finally subjected to $100 \%$ ethanol and $\mathrm{CO}_{2}$ to achieve the critical point drying. An aliquot of $20 \mu \mathrm{L}$ of bacterial pellets were applied on poly-L-lysine slide, and subjected to gold coating and observed under ZeissEvo 40 scanning electron microscope.

\section{Statistical analysis}

All experiments were carried out in triplicate and statistical analysis was by Graph Pad Prism, version 4.00 for Windows (GraphPad Software, San Diego California USA). Data are presented as mean $\pm S D$, and $p<0.05$ for leishmanicidal assay and $p<0.001$ for antibacterial assay, were set as statistically significant.

\section{RESULTS}

The in-vitro leishmanicidal activity was checked against promastigotes and intracellular amastigotes of $L$. donovani. The result of the analysis is represented in Table 2.

The antibacterial screening was conducted by agar well diffusion assay using bioassay guided fractions against Gram-positive $S$. aureus and three Gram-negative strains viz., Serratia $s p$, Acinetobacter sp. and E. coli MDR clinical isolates. The result of the analysis is represented in Table 3.

Table 2: In vitro leishmanicidal activity against promastigotes and intracellular amastigotes of $L$. donovani with fractions of $W$. tomentosa

\begin{tabular}{|c|c|c|}
\hline Extract & $\begin{array}{c}\mathrm{IC}_{50} \\
\text { (mean } \pm \mathrm{SD}, \mu \mathrm{g} / \mathrm{mL}) \\
\text { promastigotes }\end{array}$ & $\begin{array}{c}\mathrm{IC}_{50} \\
\text { (mean } \pm \mathrm{SD}, \mu \mathrm{g} / \mathrm{mL}) \\
\text { amastigotes }\end{array}$ \\
\hline$n$-Hex & $89.85 \pm 0.84$ & $48.3 \pm 0.40$ \\
\hline $\begin{array}{l}\text { DCM } \\
\text { EtOAc } \\
\text { Aq }\end{array}$ & $\begin{aligned} & 500 \\
& 500 \\
> & 1000\end{aligned}$ & $\begin{array}{c}250 \\
250 \\
> \\
1000\end{array}$ \\
\hline $\begin{array}{l}\text { Control } 1 \text { (amphotericin B) } \\
\text { Control } 2 \text { (miltefosine) }\end{array}$ & $\begin{array}{l}0.055 \pm 0.5 \\
8.11 \pm 0.36\end{array}$ & $\begin{array}{l}0.25 \pm 0.48 \\
4.37 \pm 0.51\end{array}$ \\
\hline
\end{tabular}


Table 3: Antibacterial activity of $W$. tomentosa plant fractions against four MDR clinical isolates

\begin{tabular}{lccccc}
\hline MDR bacterial isolates & n-Hex & DCM & EtOAc & Aqueous & $\begin{array}{c}\text { Positive control } \\
\text { (tetracycline) }\end{array}$ \\
\hline E. coli (2461) & $10.6 \pm 0.9$ & $18.3 \pm 0.8$ & $11.1 \pm 0.3$ & $10.3 \pm 0.4$ & $21.79 \pm 0.58$ \\
Acinetobacter sp.(2457) & $20.7 \pm 0.5$ & $16.2 \pm 0.2$ & $12.1 \pm 0.6$ & $9.2 \pm 0.3$ & $25.33 \pm 0.50$ \\
S. aureus (2413) & $24.1 \pm 0.3$ & $18.5 \pm 0.2$ & $18.7 \pm 0.7$ & $8.0 \pm 0.2$ & $25.76 \pm 0.58$ \\
Serratia sp.(2442) & $15.2 \pm 0.5$ & $16.1 \pm 0.3$ & $17.1 \pm 0.6$ & $9.7 \pm 0.1$ & $22.33 \pm 0.57$ \\
\hline
\end{tabular}

Antibacterial activity expressed as diameter of zone of inhibition in $\mathrm{mm}$ including $6 \mathrm{~mm}$ as diameter of the well. Values represented as mean $\pm S D$ of three replicates. All compounds were tested at concentration of $1 \mathrm{mg} / \mathrm{mL}$; $30 \mu \mathrm{g}$ Tetracycline discs were used as positive control

The antibacterial activity was also evaluated by determining MIC values against the selected strains. The MIC value of $S$. aureus and $E$. coli lied in the range of $62.5-125 \mu \mathrm{g} / \mathrm{mL}$ (Table 4). Cell cytotoxicity of the active fraction was evaluated at MIC and twice MIC concentration against chick embryo culture based fibroblast cells and the result was well within the permissible limit.

To know the occurrence of different classes of phytochemicals in the fractions, qualitative analysis for alkaloids, flavonoids, steroids, reducing sugar, cardiac glycosides, terpenoids, anthraquinones, tannins, phlobatanins and saponins had been conducted and being presented in Table 5.

In order to gain an insight into the chemical constituents of $n$-Hex fraction of $W$. tomentosa, GC-MS analysis was performed. The constituents were identified by comparing their retention indices (RI) with those stored on GC MS database. The RI of each compound was determined in relation to a homologous series of $n$-alkanes $\left(\mathrm{C}_{7}-\mathrm{C}_{33}\right)$ under the same operating conditions. The GC - MS profile of $W$. tomentosa $n$-Hex fraction showed the presence of twenty compounds as revealed in Table 6.

Table 4: Minimum inhibitory concentration (MIC) and minimum bactericidal concentration (MBC) of the most potent $n$-Hex fraction of $W$. tomentosa

\begin{tabular}{lcccc}
\hline \multirow{2}{*}{ Test organism } & MIC $^{\mathbf{a}}$ & MIC $^{\mathbf{a}}$ & MBC & MBC \\
\cline { 2 - 5 } & $\boldsymbol{n}$-Hex & Tetracycline & $\boldsymbol{n}$-Hex & Tetracycline \\
\hline E. coli (2461) & 125 & 0.5 & 250 & $>0.25$ \\
S. aureus (2413) & 62.5 & 0.8 & 62.5 & 0.5 \\
Acinetobacter sp & 250 & 2 & 250 & $>1$ \\
(2457) & 250 & 1.2 & 500 & $>2$ \\
Serratia sp (2442) & & & & \\
\hline
\end{tabular}

${ }^{a}$ Results are presented as MIC 90 values determined by microdilution method and expressed in $\mu \mathrm{g} / \mathrm{mL}$. Experiments were carried out in triplicate and results are expressed as mean of three replicate experiments. All crude extracts or fractions were dissolved in $0.2 \%$ DMSO and distilled water

Table 5: Phytochemical profile of soluble fractions of methanol extract of $W$. tomentosa

\begin{tabular}{|c|c|c|c|c|}
\hline $\begin{array}{l}\text { Phytochemical } \\
\text { class }\end{array}$ & $n$-hex & DCM & EtOAc & $\begin{array}{l}\text { Aqueous } \\
\text { residue }\end{array}$ \\
\hline Alkaloids & ++ & + & ++ & - \\
\hline Flavonoids & ++ & ++ & ++ & ++ \\
\hline Steroid & + & + & ++ & - \\
\hline Tannins & + & + & + & + \\
\hline $\begin{array}{l}\text { Reducing } \\
\text { sugars }\end{array}$ & - & - & - & ++ \\
\hline $\begin{array}{l}\text { Cardiac } \\
\text { Glycosides }\end{array}$ & + & ++ & ++ & + \\
\hline Triterpenoids & + & ++ & - & + \\
\hline Anthraquinones & - & - & - & - \\
\hline Phlobatanins & ++ & ++++ & +++ & + \\
\hline
\end{tabular}


Table 6: GC-MS analysis of $n$-Hex fraction of $W$. tomentosa

\begin{tabular}{|c|c|c|c|c|c|c|}
\hline Peak & $\begin{array}{c}\mathrm{RT} \\
(\mathrm{min})\end{array}$ & Area (\%) & $\mathbf{R I}^{\mathbf{b}}$ & Name of compound ${ }^{a}$ & $\begin{array}{l}\text { Class of } \\
\text { compound }\end{array}$ & Activities reported \\
\hline 1 & 23.076 & 1.84 & 1670 & $\begin{array}{l}\text { Bisabolol oxide b (furan } \\
\text { oxide) }\end{array}$ & $\begin{array}{l}\text { Sesquiterpene } \\
\text { alcohol }\end{array}$ & $\begin{array}{l}\text { Anti-inflammatory, } \\
\text { antioxidant, } \\
\text { apoptosis inducer }\end{array}$ \\
\hline 2 & 28.63 & 6.3 & 1934 & $\begin{array}{l}\text { Heptadecanoic acid, methyl } \\
\text { ester }\end{array}$ & $\begin{array}{l}\text { Fatty acid } \\
\text { methyl ester }\end{array}$ & $\begin{array}{l}\text { Antibacterial, antifung } \\
\text { al, antioxidant }\end{array}$ \\
\hline 3 & 28.686 & 1.82 & 1937 & 2,3-diisopropylquinoxaline & $\begin{array}{l}\text { Quinoxaline } \\
\text { derivative }\end{array}$ & Not reported \\
\hline 4 & 29.399 & 14.4 & 1973 & Tridecanoic acid & $\begin{array}{l}\text { Saturated fatty } \\
\text { acid }\end{array}$ & $\begin{array}{l}\text { Antioxidant and } \\
\text { perfumery }\end{array}$ \\
\hline 5 & 31.891 & 10.99 & 2105 & Linolelaidic acid, methyl ester & $\begin{array}{l}\text { Fatty acid } \\
\text { methyl ester }\end{array}$ & $\begin{array}{l}\text { Inhibit production of } \\
\text { uric acid, urine } \\
\text { acidifier }\end{array}$ \\
\hline 6 & 32.004 & 6.54 & 2111 & Linoleic acid, methyl ester & $\begin{array}{l}\text { Fatty acid } \\
\text { methyl ester }\end{array}$ & $\begin{array}{l}\text { Antibacterial, } \\
\text { antifungal }\end{array}$ \\
\hline 7 & 32.544 & 37.72 & 2142 & 1-Phenyl-2-pentanone & Aryl ketone & Insecticidal \\
\hline 8 & 32.664 & 3.42 & 2148 & Cyclodecene & Acyclic alkene & $\begin{array}{l}\text { Not reported } \\
\text { Agonist of the ER- }\end{array}$ \\
\hline 9 & 33.115 & 0.51 & 2174 & 2-Nitro-2-methyl-1-propanol & Aliphatic alcohol & $\begin{array}{l}\text { alpha signalling } \\
\text { pathway }\end{array}$ \\
\hline 10 & 35.355 & 5.37 & 2303 & 2-methyl-3-buten-1,2-diol & Aliphatic diol & Not reported \\
\hline 11 & 35.429 & 1.75 & 2307 & $\begin{array}{l}\text { 1-(2-hydroxyethoxy)- } \\
\text { pentadecane }\end{array}$ & $\begin{array}{l}\text { Aliphatic } \\
\text { hydrocarbon }\end{array}$ & Not reported \\
\hline 12 & 35.942 & 0.51 & 2338 & Hexanoic acid, methyl ester & $\begin{array}{l}\text { Fatty acid } \\
\text { methyl ester }\end{array}$ & $\begin{array}{l}\text { Flavouring agent, } \\
\text { exhibit beta-oxidant } \\
\text { function, found in } \\
\text { melon, raspberry, } \\
\text { wine grapes etc }\end{array}$ \\
\hline 13 & 38.886 & 1.4 & 2508 & Pentadecane & $\begin{array}{l}\text { Alkane } \\
\text { hydrocarbon }\end{array}$ & $\begin{array}{l}\text { Volatile oil } \\
\text { component/ } \\
\text { antibacterial }\end{array}$ \\
\hline 14 & 38.966 & 0.5 & 2512 & 2,4,4-trimethyl-2-penten-1-ol & Aliphatic alcohol & Not reported \\
\hline 15 & 39.524 & 0.25 & 2538 & Acetic acid, methyl ester & $\begin{array}{l}\text { Fatty acid } \\
\text { methyl ester }\end{array}$ & $\begin{array}{l}\text { VOC emission from } \\
\text { branches of plants }\end{array}$ \\
\hline 16 & 43.42 & 3.41 & 2198 & Docosane & $\begin{array}{l}\text { Acyclic } \\
\text { hydrocarbons }\end{array}$ & Antibacterial \\
\hline 17 & 43.597 & 0.51 & 2722 & $\begin{array}{l}\text { Acetic acid, trichloro-, propyl } \\
\text { ester }\end{array}$ & Fatty acid & Not reported \\
\hline 18 & 44.028 & 0.56 & 2746 & 2-Methylpentanoic acid & Fatty acid & $\begin{array}{l}\text { Food-flavor } \\
\text { ingredient, } \\
\text { fragrances, soaps } \\
\text { etc. }\end{array}$ \\
\hline 19 & 45.729 & 0.52 & 2849 & Acetonyl decyl ether & Ether & Not reported \\
\hline 20 & 46.728 & 1.68 & 2911 & Hexadecane & $\begin{array}{l}\text { Alkane } \\
\text { hydrocarbon }\end{array}$ & $\begin{array}{l}\text { Volatile oil } \\
\text { component/ } \\
\text { antibacterial }\end{array}$ \\
\hline
\end{tabular}

GC-MS data revealed that four chemical classes including fatty acid and fatty acid esters (40.06 $\%$ ), aryl ketone (37.72 \%), hydrocarbon (11.66 $\%)$ and aliphatic alcohol (6.34\%) constituted almost $95.8 \%$ of the total constituents (Figure 1).

The SEM result showed substantial morphological changes in the treated cells compared to the untreated negative control (Figure 2).

\section{DISCUSSION}

Based on the results, the $n$-Hex fraction of $W$. tomentosa demonstrated substantial leishmanicidal activity against promastigotes and intracellular amastigotes, while the other fractions displayed much lower potential.

It is well documented that $\mathrm{IC}_{50}<100 \mu \mathrm{g} / \mathrm{mL}$ is 


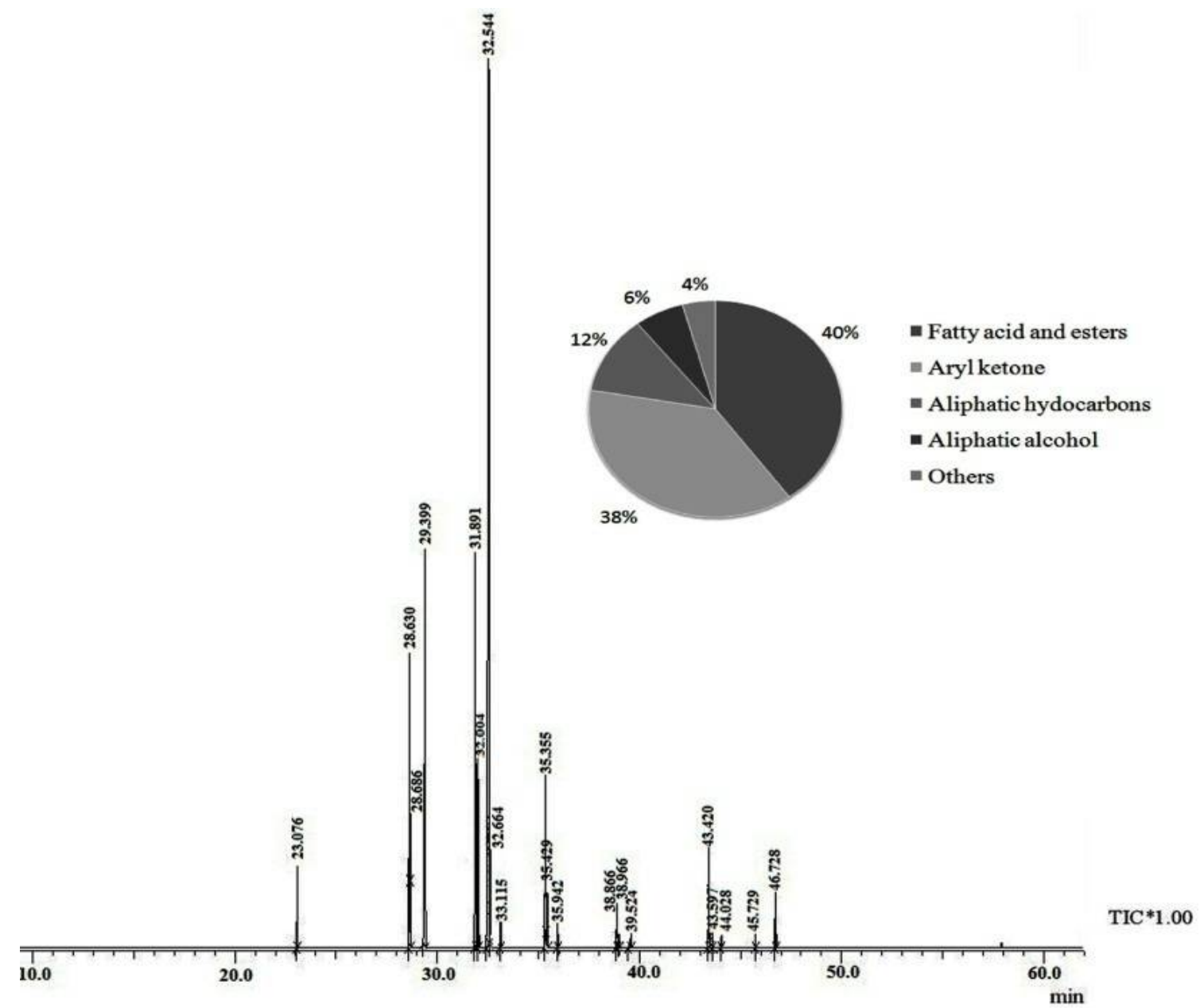

Figure 1: GC-MS spectra of $n$-Hex fraction. The compounds are classified in four major chemotypes and miscellaneous represented as pie-chart
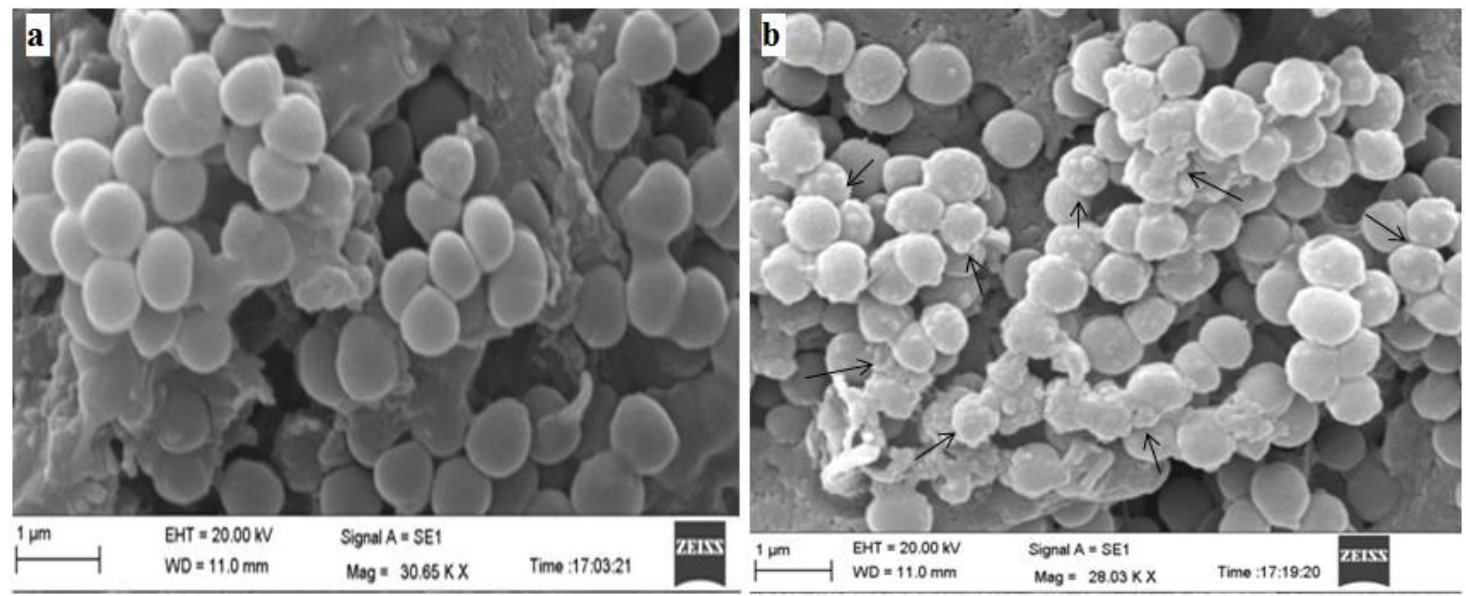

Figure 2: Scanning electron micrograph of $S$. aureus treated with $W$. tomentosa $n$-Hex fraction. Cells were treated as described in Experimental section. The untreated $S$. aureus cells (2a) can be seen round and intact. The treated cells, i.e. $S$. aureus with $W$. tomentosa $n$-Hex fraction (2b) can be seen with blebs and distortions at $30000 \times$ magnification

considered as potent while, $100-625 \mu \mathrm{g} / \mathrm{mL}$ represent moderate activity [19]. The antibacterial activity evaluated against Grampositive and three Gram-negative clinical isolates identified $n$-Hex fraction of $W$. tomentosa possessing maximum potency against $S$. aureus with maximum zone of inhibition (ZI) of $24.1 \pm 0.3$ $\mathrm{mm}$, followed by Acinetobacter sp. while, the DCM and EtOAc fractions were moderately active against $S$. aureus, Serratia $s p$. and E.coli. 
Also, it is well established that $\mathrm{Zl}$ in the range of $11-15 \mathrm{~mm}$ is considered as high, $16-20 \mathrm{~mm}$ is considered as very high and more than $21 \mathrm{~mm}$ is considered as significant [20]. Minimum inhibitory concentration against the selected strains was determined for $n$-Hex fraction, the values against $S$. aureus and $E$. coli lied in the range of 62.5 $125 \mu \mathrm{g} / \mathrm{mL}$.

It is worthy to mention that though, a number of plant extracts exhibit promising biological activity but majority of them suffers from high toxicity on normal cells and could not be considered for drug development [21]. However, our study identified $n$-Hex fraction possessing both leishmanicidal and antibacterial activity without any cell cytotoxicity.

The result of the qualitative test provides a broad idea about phytochemical classes and their relative proportion in a particular fraction. GC MS analysis data revealed that four chemical classes including fatty acid and fatty acid esters (40.06\%), aryl ketone (37.72\%), hydrocarbon $(11.66 \%)$ and aliphatic alcohol (6.34\%) constituted almost $95.8 \%$ of the total constituents. Literature search revealed that six compounds were reported to have antibacterial activity, four compounds were known for their fragrance and seven compounds had not been reported for any biological activity. The source of quinoxaline derivative in GC - MS spectrum is not known. However, it is well known fact that quinoxaline derivatives are used as herbicides in soil and also it is produced by chemical degradation of certain chemicals in soil and soil fungal cultures [22]. Though, 2-nitro-2-methyl-1propanol, had been reported in a number of GC MS spectrum [23], but it is difficult to justify the occurrence of the compound $(0.51 \%)$ in plant extract. The use of fatty acids is safe and finds wide applications in the field of medicine, agriculture and food preservation due to its broad spectrum and non-specific mode of action.

Better performance demonstrated by non-polar fractions might involve the lipophilic constituents, which causes disturbance to the lipid portion of the plasma membrane, leading to a loss of permeability and leakage of intracellular materials [24], this might be the case as the Scanning Electron Microscopy (SEM) showed morphological changes induced by the extract and revealed that $n$-Hex fraction of $W$. tomentosa induces deleterious morphological changes in the bacterial cell membrane of $S$. aureus indicating membrane damage in bacterial cells.

\section{CONCLUSION}

The investigation conducted by bioassay guided fractionation for leishmanicidal and anti-bacterial activity identified $n$-Hex fraction of $W$. tomentosa as the most active fraction. The GC - MS profile was distinctive in nature which could be used further to differentiate Waldheimia tomentosa from other Waldheimia species. The occurrence of leishmanicidal and antibacterial activity in the same fraction could be beneficial for commercialization of the fraction in herbal medicine and food preservation.

\section{DECLARATIONS}

\section{Acknowledgement}

The authors acknowledge Department of Science and Technology, Government of India for financial support, Dr. Ajay Kumar, JNU, New Delhi for GC-MS support, Dr. Ruchita Pal, JNU, New Delhi for Scanning electron microscopy instrument support and Dr. A.K. Chauhan, Founder President, Amity University, for his continuous motivation and encouragement.

\section{Conflict of Interest}

No conflict of interest associated with this work.

\section{Contribution of Authors}

The authors declare that this work was done by the authors named in this article and all liabilities pertaining to claims relating to the content of this article will be borne by them.

\section{Open Access}

This is an Open Access article that uses a funding model which does not charge readers or their institutions for access and distributed under the terms of the Creative Commons Attribution License (http://creativecommons.org/licenses/by/ 4.0) and the Budapest Open Access Initiative (http://www.budapestopenaccessinitiative.org/rea d), which permit unrestricted use, distribution, and reproduction in any medium, provided the original work is properly credited.

\section{REFERENCES}

1. Ballabh B, Chaurasia OP, Ahmed Z, Singh SB. Traditional medicinal plants of cold desert Ladakh-used against kidney and urinary disorders. J Ethnopharmacol 2008; 118: 331-399. 
2. Buth GM, Navchoo IA. Ethnobotany of ladakh (India) plants used in healthcare. J Ethnobiol1988; 8(2): 185194.

3. Giorgi A, Panseri S, Mattara MS, Andreis C, Chiesa LM. Secondary metabolites and antioxidant capacities of Waldheimia glabra (Decne.) Regel from Nepal. J Sci Food Agr2012; 93(5): 1026-1034.

4. Rocha LG, Almeida JR, Macêdo RO, Barbosa-Filho JM. A review of natural products with antileishmanial activity. Phytomed2005; 12: 514-535.

5. Islamuddin M, Chouhan G, Want MY, Tyagi M, Abdin MZ, Sahal $D$ and Afrin F. Leishmanicidal activities of Artemisia annua leaf essential oil against Visceral Leishmaniasis. Front Microbiol 2014; 5: 626. .https://doi.org/10.3389/fmicb.2014.00626

6. Mc Adam AJ, Sharpe AH. Infectious diseases. In: Robbins and Cotran Pathologic Basis of Disease. Elsevier Publishers, New Delhi, Edition 7, 2004: 403405.

7. Sundar S, Chakravarty J. An Update on Pharmacotherapy for Leishmaniasis. Expert Opin Pharmacother 2015; 16(2): 237-252.

8. Abreu AC, McBain AJ, Simoes M. Plants as sources of new antimicrobials and resistance-modifying agents. Nat Prod Rep 2012; 29: 1007-1021.

9. Mishra P, Sinha S, Kumar S, Bhushan S, Viswakarma $R A$, Ghosal S. Two new amides with cytotoxic activity from the fruits of Piper longum. J Asian Nat Prod Res 2011; 13(2): 143-148.

10. Rajesh $P$, Latha $S$, Selvamani $P$, Kannan RV. Phytochemical screening and toxicity studies on the leaves of Capparissepiaria Linn. (Capparidaceae). J Basic Clin Pharma 2010; 1(1): 001.

11. Sawant RS, Godghate AG. Qualitative phytochemical screening of rhizomes of Curcuma longa Linn. IJSET 2013; 2(4): 634-641.

12. CLSI, Performance Standards for Antimicrobial Disk Susceptibility Tests, Approved Standard, 7th ed., CLSI document M02-A11.

13. Rojas JJ, Ochoa VJ, Ocampo SA, Muñoz JF. Screening for antimicrobial activity of ten medicinal plants used in Colombian folkloric medicine: A possible alternative in the treatment of non-nosocomial infections. $B M C$ Complement Altern Med 2006; 6: 2-10.
14. Wiegand I, Hilpert K, Hancock REW. Agar and broth dilution methods to determine the minimal inhibitory concentration (MIC) of antimicrobial substances. Nat Protoc 2008; 3(2): 163-175.

15. Celiktas OY, Girgin G, Orhan H, Wichers HJ, Bedir E, Vardar-Sukan $F$. Screening of free radical scavenging capacity and antioxidant activities of Rosmarinus officinalis extracts with focus on location and harvesting times. Eur Food Res Tech 2007; 224(4); 443-451.

16. Sharma $U$, Singh $D$, Kumar $P$, Dobhal, $M P$, Singh $S$. Antiparasitic activity of plumericin \& isoplumericin isolated from Plumeria bicolor against Leishmania donovani. Indian J Med Res 2011; 134(5): 709-716.

17. Kakad SB, Dhembare AJ. The cytotoxicity of different plant extract on chick embryo fibroblast cell line. Arch Appl Sci Res 2014; 6(4): 139-142.

18. Tang QL, Kang AR, Lu CX. Phytochemical analysis, antibacterial activity and mode of action of the methanolic extract of Scutellaria barbata against various clinically important bacterial pathogens. Int $J$ Pharm 2016; 12: 116-125.

19. Fokialakis N, Kalpoutzakis E, Tekwani BL, Khan SI, Kobaisy M, Skaltsounis AL, Duke SO. Evaluation of the antimalarial and antileishmanial activity of plants from the Greek island of Crete. J Nat Med 2007; 61: 38. doi:10.1007/s11418-006-0013-y.

20. Khanam Z. Wen CS, Bhat IUIH. Phytochemical screening and antimicrobial activity of root and stem extracts of wild Eurycoma longifolia Jack (Tongkat Ali).J King Saud Uni Sci 27 2015; 23-30.

21. Peters JS, Chin CK. Inhibition of photosynthetic electron transport by palmitoleic acid is partially correlated to loss of thylakoid membrane proteins. Plant Physiol Biochem 2003; 41: 117-124.

22. Robert TR: Metabolic pathways of agrochemicalsHerbicides and plant growth regulators. RSC Publishers, 1998; $p 260$.

23. Barry EF, Grob RL. Columns for Gas Chromatography: Performance and Selection. Wiley, 2007; $p 162$.

24. Atta-ur-Rahman, Samreen, Atia-tul-Wahab, Choudhary MI. Discovery of leishmanicidal agents from medicinal plants. Pure Appl Chem 2008; 80: 1783-1790. 